\title{
A Pragmatic Study of Apologies Posted on Weibo by Chinese Celebrities
}

\author{
Xu Zhanghong*, Li Yanan \\ School of English for International Business, Guangdong University of Foreign Studies, Guangzhou, China \\ Email address: \\ 1458975262@qq.com (Xu Zhanghong),1016614066@qq.com (Li Yanan) \\ ${ }^{*}$ Corresponding author
}

\section{To cite this article:}

Xu Zhanghong, Li Yanan. A Pragmatic Study of Apologies Posted on Weibo by Chinese Celebrities. International Journal of Literature and Arts. Special Issue: Humanity and Science: China's Intercultural Communication with the Outside World in the New Era.

Vol. 8, No. 2, 2020, pp. 52-61. doi: 10.11648/j.ijla.20200802.14

Received: February 27, 2020; Accepted: March 10, 2020; Published: March 31, 2020

\begin{abstract}
As we are living in the "Age of Apology" (Brooks, 1999), our ability to say "I'm sorry" does matter considerably, for an appropriate apology would not only express regret but also contribute to interpersonal relationship management and image restoration. Although apology as a social phenomenon has been extensively studied in the English-speaking world, Chinese apologies have not drawn due attention from linguists and management scientists. This paper investigates formal apologies made by Chinese celebrities between 2018 and 2019 in the context of social media by scrutinizing 30 cases collected from Weibo, a Chinese micro-blogging site. Based on Cross-Cultural Speech Act Realization Patterns (CCSARP) and image repair strategies, it is found that (1) IFID (Illocutionary Force Indicating Device) is the most common strategy in apologies, followed by Explanation or Account, whereas Offer of Repair is the least; (2) In terms of image restoration, Chinese celebrities tend to employ Reduce Offensiveness and Mortification to offset negative impressions; (3) Being shamed or being embarrassed (“差愧”) and self-examination (“反省”) are specific IFID types in Chinese, and some mitigation strategies distinct from those in other languages are found. The research has revealed the specific features of Chinese apologies on social media and will shed light on ways of image management for the ordinary Chinese in general and Chinese celebrities in particular.
\end{abstract}

Keywords: Apologies, Image Repair, Weibo, Celebrities

\section{Introduction}

As Brooks observed, we are living in the "Age of Apology" and the only thing that has changed significantly over the years is the human ability to say "I'm sorry" [1]. An apology can not only express regret today but also contribute to interpersonal relationship management and image restoration. A sincere apology can alleviate rather than aggravate the situation, placate victims and netizens, and keep social harmony and stability. In recent years, due to the unprecedented frequency and speed of Internet interaction, many events triggered heated discussions on social media within a short time, which increases the difficulty in lying, denying, or concealing the truth when a crisis breaks out. Thus, confronted with crises or scandals that arouse controversies, people tend to make apologies on social media like Weibo instead of traditional media to eliminate harmful influences.
Launched in 2009, Weibo, a Chinese social networking service modeled after Twitter, has become one of the most influential social media platforms for people to exchange information [2]. Characterized by timeliness, interactivity, and anonymity [3], it now has billions of users from all over the world, and the number of monthly active users reaches to 486 million. With the development of Weibo and its robust user base, the government develops E-government on it, facilitating communication between the government and the public and enhancing its public recognition and impression [4, 5]. In the meantime, influential corporations and individuals regard Weibo as a timely and effective channel of communication, paying attention to the interaction with their followers to publicize themselves and shape positive images.

Linguist and management experts have investigated apologies from different perspectives and made different findings. Most of linguistic studies on apology focus on the composition of apologies by categorizing their pragmatic 
strategies [6-8]. Empirical research was conducted to analyze apology, as a speech act, in different languages and cultures, attempting to figure out some universal patterns [9-12]. In the field of management, scholars attach great importance to the effects and strategies of apologies as an image restoration device [13]. Benoit proposed five broad categories of image repair strategies and analyzed some apologies made by celebrities, politicians and corporations in traditional media [14]. Based on his theory, scholars also analyze apologies posted on Twitter and YouTube, with an increasing number of apologies posted on social media nowadays [15-17].

However, research on apology based on the Chinese language, one of the most spoken languages worldwide, is far from enough compared with that in English and some other languages. Kadar, Ning and Ran suggest that Chinese is often referred to as a non-apology culture, and this stereotype leads to very little research on Chinese apologies [12]. However, explicit apology is now gradually required in China, and apologies made by the Chinese become a significant social phenomenon. In this study, we will attempt to figure out some culture-specific features through the analysis of Chinese apology. Moreover, social media has a great advantage in communication, and the center of attention in this field has shifted to social media. Weibo is an influential social media platform with billions of users, yet it has not received so much attention as Twitter or YouTube.

Therefore, it is of great significance to investigate Chinese apologies posted on Weibo to examine the pragmatic strategies of Chinese apologies and to investigate how Chinese celebrities cope with crises or manage the image. The present research attempts to address the pragmatic strategies in Chinese apologies posted on Weibo and the way the celebrities repair their images on social media. This paper is structured as follows. In section 2 the literature on apology and image repair is reviewed, followed by a brief introduction of CCSARP and image repair theory in section 3 Section 4 and 5 will present the data collection and data analysis, and section 6 concludes the paper.

\section{Apology and Image Repair}

This section will firstly review related studies on apology and image repair, and then make a critical evaluation of the previous research, pointing out the strengths and weaknesses.

\subsection{Apology}

In recent decades, the apology has become an important topic in linguistics, especially in the field of pragmatics. Many scholars have discussed the apology from the perspective of speech act theory, politeness principle, and the concept of face [18-21]. Brown and Levinson suggest that making an apology can be seen as a face-threatening act [22]. After the addresser damages the addressee's negative face-the desire to be unimpeded in one's actions, s/he should apologize, which also damages the apologizer's positive face-the desire to be approved of.

A number of researchers have investigated pragmatic strategies for making apologies, and many have conducted various forms of surveys or empirical research to testify their theories. A classic categorization of apology strategies is proposed by Olshtain and Cohen [6], including five categories: (1) an expression of apology, (2) an explanation or account of the situation, (3) an acknowledgment of responsibility, (4) an offer of repair, and (5) a promise of forbearance. Based on the naturally occurring data in the New Zealand corpus, Holmes revises Olshtain and Cohen's categorization and develops four categories, each of which has several subcategories [7]. Trosborg proposes a different taxonomy with five categories: explicit denial or implicit denial occurs when the offender thinks that there is no need to apologize; giving a justification, blaming someone else, or attacking the complainer occurs when the offender accepts to apologize [8].

Blum-Kulka and Olshtain's Cross-Cultural Speech Act Realization Patterns (CCSARP) is the most well-known theory after the 1980 s $[9,23]$. In order to investigate the issue of universality, the CCSARP project compares across eight languages the realization patterns of requests and apologies and makes a comparison between native and non-native speakers through several versions of Discourse Completion Test (DCT). Hence, they devise Illocutionary Force Indicating Device (IFID), direct realization of an apology, and four strategies for performing the act of apologizing: Taking on Responsibility, Explanation or Account, Offer of Repair, and Promise of Forbearance.

Based on CCSARP, Shahrokhi and Mohd investigate apology strategies employed by Persian males and identify a new strategy, "underestimating the offense by humor", as a prevalent culture-specific strategy among the Persian [10]. They also find that the most frequently used formula is IFID, followed by Taking on Responsibility while they don't find any instances of Promise of Forbearance. After combining the taxonomy of Olshtain and Cohen, Trosborg, and Bergman and Kasper and comparing Romanian apologies with American apologies elicited from the show Friends, Demeter reveals that more than half of the Romanian participants preferred two strategies and more than 80 percent of the apologies contain a combination of two to five strategies [24].

The above categorizations are very comprehensive and involve many languages. Just as Demeter insists, the apology speech act is culture-specific, and we should choose categories in the respective culture in our study [24]. However, most of the previous studies pursue the universal patterns, regardless of cultural diversity, especially between eastern culture and western culture. Furthermore, as Chinese is stereotypically regarded as a non-apology culture [12], very few studies investigate the strategies employed in Chinese apologies, propose specific patterns, or make a comparison between Chinese and other languages. Accordingly, this study is to investigate whether the above categorization and formulas can be applied in Chinese apology, and what strategies are preferred by Chinese celebrities in performing the speech act of apologizing. More 
specifically, the present study attempts to find out how Chinese celebrities apologize on social media during crises or scandals to alleviate bad influence and restore the positive image.

\subsection{Image Repair}

An apology involves repairing and restoring the image of an individual or an organization. Benoit proposes five general strategies for image restoration, each having several tactics [14]. Based on this theory, Benoit analyzes and compares entertainment image repair, political and corporate image repair, and discovers that celebrities don't attack their competitors, corporate officials can fire employees and distance the company from the crisis, and politicians needn't face litigation.

Different types of image repair require different strategies, and the results will be influenced by the extent of the crisis. Entertainment figures and politic figures tend to utilize Bolstering. By analyzing Hugh Grant's serial interviews after his scandal, Benoit reveals how Grant employed Mortification, Bolstering, Attacking the Accuser, and Denial to restore his image and create an impression of an honest, frank, and self-effacing man [25]. In addition to Bolstering, Queen Elizabeth, President Bush and President Obama also employ Defeasibility in their speeches when faced with a threat to their images [26-28]. Queen Elizabeth utilized Defeasibility to explain the royal family's reaction-they were too shocked to respond immediately and denied the allegation of indifference. President Obama attempted to lower people's expectations by Minimization, admitting that he is not a perfect president, and utilized Defeasibility in his defense, arguing that the system is extremely complex and difficult to control. Although their image repair work is generally appropriate and effective, President Bush was unsuccessful in repairing his image. First, the use of Bolstering is ineffectual; second, the use of Defeasibility emphasizes his inability; third, his Corrective Action is not persuasive; finally, he doesn't apologize at all. Benoit suggests that Defeasibility is not a good choice for presidents to use [27], but his case analysis of Queen Elizabeth and President Obama clearly contradicts himself.

With the development of social networks, apology forms have increasingly enriched. However, researchers tend to concentrate on apology discourse on mainstream media like television interviews, newspapers, and journal articles, and very few researchers pay attention to social media platforms like micro-blog. Benoit's image repair theory can be used in analyzing apologies and audience perceptions on social media. Page focuses on corporate apologies posted on Twitter and reveals the infrequent use of Explanation or Account and great use of Offer of Repair, which is rather different from apologies posted by ordinary Twitter members [15]. Sandlin and Gracyalny analyze YouTube apologies made by public figures and find that Mortification is the most frequently utilized image repair strategy, followed by Reducing Offensiveness and Corrective Action [16].

Since Weibo, the Chinese version of Twitter, has entered the mainstream of social networks, most organizations and individuals choose to make apologies through Weibo when dealing with crisis events that require an apology. Weibo provides us with abundant apology posts to investigate image repair work in China. However, we can only find very few studies on Chinese apologies, especially on social media, which are in want of further investigation. Thus, this paper attempts to explore the pragmatic strategies employed by Chinese celebrities in apologizing on Weibo and the ways of image repair after crises or scandals.

\section{Analytical Framework}

According to Page [15], scholars in linguistic and rhetoric fields focus on an apology's forms and functions respectively, in which CCSARP and image repair theory are frequently employed. The data collected in this paper will be analyzed using the CCSARP coding scheme and image repair theory.

\subsection{CCSARP}

Blum-Kulka and Olshtain believed that by apologizing, the speaker committed that what they have done has violated the social norm to some extent [9]. But how can we recognize whether an apology is qualified to perform the speech act? In accordance with CCSARP, the linguistic realization of apology speech act can take the form of the following strategies:

1) Illocutionary Force Indicating Device (IFID).

2) An expression of the speaker's responsibility for the offense.

3) An explanation or account of the cause which brought about the offense.

4) An offer of repair.

5) A promise of forbearance.

\subsection{Image Repair Theory}

According to Benoit [14], image management is vital to organizations and individuals in the field of public relations, especially in the case of crises and scandals. Image repair theory concentrates on message options, providing five broad categories of image restoration strategies, namely Denial, Evade Responsibility, Reduce Offensiveness, Corrective Action, and Mortification, which are tabulated as table 1

Table 1. Benoit's image repair strategies.

\begin{tabular}{lll}
\hline General Strategy & Tactic & Key Characteristic \\
\hline Denial & Simple denial & Did not perform act \\
& Shift blame & Act performed by another \\
Evade responsibility & Provocation & Responded to act of another \\
\hline
\end{tabular}




\begin{tabular}{lll}
\hline General Strategy & Tactic & Key Characteristic \\
\hline & Defeasibility & Lack of information or ability \\
& Accident & Act was a mishap \\
Geduce offensiveness & Meant well in act & \\
& Bolstering & Stress good traits \\
& Minimization & Act not serious \\
& Differentiation & Act less offensive \\
& Transcendence & More important considerations \\
& Attack accuser & Reduce credibility of accuser \\
Corrective Action & Compensation & Reimburse victim \\
Mortification & & Plan to solve or prevent problem \\
\hline
\end{tabular}

\section{Data Collection and Method of Analysis}

The data consist of 30 formal apologies made by Chinese celebrities on Weibo between 2018 and 2019 based on the following standards. First, each of these celebrities has millions of followers, in the capacity of singer, actor, entrepreneur, host, or film-director. Second, because of their crises or scandals like domestic violence, academic misconduct, copyright infringement, inappropriate remarks and so on, all of them are facing unfavorable Trendings on Weibo, the hottest topics discussed by millions of people, and are under serious criticism. Third, these apologies have thousands of reposts, comments, and likes, from which we can evaluate netizen's attitudes.

The procedure of analysis proceeds as follows. First of all, 30 discourses of apology are analyzed following CCSARP coding manual to investigate conventional lexemes of apology in Chinese and strategies utilized in performing the speech act of apology. Each apology is evaluated by IFID, Taking on Responsibility, Explanation or Account, Offer of Repair, and Promise of Forbearance. This paper will extract and categorize the formulas of celebrities' apologies, and some details and features derived from the apologies will be discussed. Second, descriptions of image repair theory advanced by Benoit will be used to analyze how celebrities restore their images after serious crises. Besides, some mitigating strategies for displaying sincerity and evoking sympathy from netizens are identified.

\section{Data Analysis}

The data collected from Weibo will be analyzed based on the framework illustrated previously, and this section will display the results and findings.

\subsection{Apology Strategies}

Based on the data collected, we count the occurrence of each strategy in 30 apologies, and Figure 1 presents the frequency of each strategy. The result reveals that IFID is the most common pragmatic strategy employed by Chinese celebrities, followed by Explanation or Account and Taking on Responsibility, while Offer of Repair is the least used

\section{strategy.}

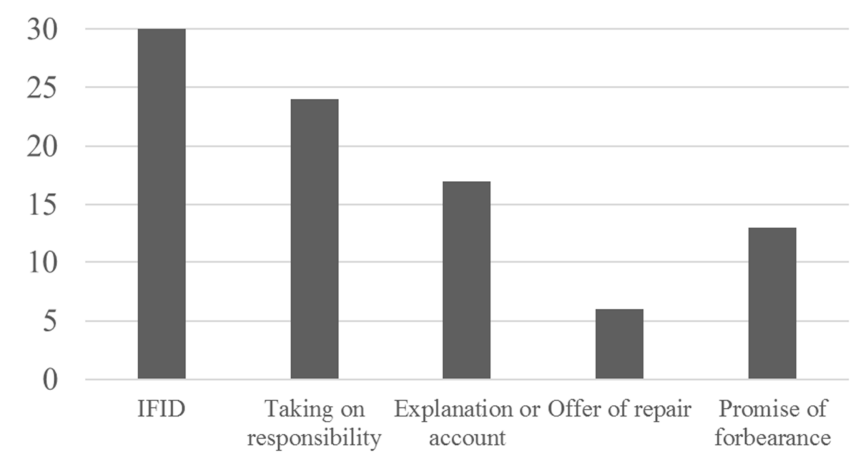

Figure 1. Frequency of strategies.

As a ritualized formulaic expression for apology, IFID can be found in any language $[9,11]$. However, compared with previous research, we can conclude that IFID is not as frequently used in English or other languages as that in Chinese. As presented in Figure 1, all of the apologies utilize at least one IFID expression, from which we can infer that Chinese celebrities tend to apologize explicitly and directly through the realization of IFIDs.

In addition, we find that celebrities prefer combining three or four strategies together to make their apologies sincere, especially the combination of IFID and Taking on Responsibility, and IFID and Explanation or Account. They also tend to use an IFID at the beginning, and then explain the situation or mistake, followed by Taking on Responsibility.

\subsubsection{IFID Types}

Blum-Kulka and Olshtain suggest that for each language there is a scale of conventionality of IFID realizations, for example, in English, the most common form is "(be) sorry" [9]. According to our research, the lexemes commonly recognized as IFID in Chinese include “道兼,抱兼,致兼,歉意(apologize), 对不起 (be sorry), 后悔 (regret), 原谅 (excuse, pardon, forgive), 羞愧 (be shamed, be embarrassed), 反省 (self-examination)". Any discourse without these lexemes will not be regarded as an apology.

It is worth noticing that the expression of "I'm embarrassed (差愧)" has been categorized as Taking on Responsibility according to Blum-Kulka, House and Kasper [29], but Afghari suggests that it belongs to direct expressions of apology in Persian [11]. We find that in Chinese, “差愧(be ashamed, be embarrassed)" implicates that someone has done something 
incorrect or inappropriate, and it should be categorized as an IFID. Likewise，“反省 (self-examination)” implicates someone check for his/her mistakes. Table 2 categorizes the types and lists examples of IFID from our data.

Table 2. Apology IFID types in Chinese.

\begin{tabular}{ll}
\hline Type & Examples \\
\hline 道歉,抱歉,致歉,歉意(apologize) & 我为我昨天发表的言论道歉 \\
& I apologize for what I have said yesterday \\
& 对不起让你们失望了 \\
对不起(be sorry) & I'm sorry to let you down \\
& 为此我感到十分的自责和后悔 \\
后悔(regret) & For this, I blame myself and regret \\
& 希望大家能够原谅我包容我 \\
原谅(excuse, pardon, forgive) & I hope you can forgive me \\
& 我对自己的所作所为深感差愧、内疚 \\
羞愧(be ashamed, be embarrassed) & I am deeply ashamed and feel guilty for what I have done \\
反省(self-examination) & 我認真反省自己的過失, 接受懲罰承擔後果 \\
\hline & I made self-examination for my mistakes, and I'm willing to accept the consequences and punishment. \\
\hline
\end{tabular}

\subsubsection{Intensification}

Intensifiers are words or phrases that can make the meaning of another word stronger. In our study, we find that all intensifiers are placed in front of the IFID to convey sincerity. Blum-Kulka and Olshtain noted three devices in apology intensification, and two of them are easily seen [9].

One device is an identifying expression within the IFID. It is evident that some intensifiers are preferred by Chinese celebrities. For example, “诚恳、诚挚、由衷、真心、真诚” are synonyms of “sincerely”, “深深、深表、深感、深切” are “deeply”, and “郑重、正式” are "seriously”, signifying that they are truly sorry for what they have done, as in the following example.

(1) 我再次向大家诚恳道慊！请大家原谅!

I sincerely apologize to you again! Please forgive me!

The other device is using multiple strategies. In order to emphasize that they are making formal apologies, Chinese celebrities tend to utilize several strategies simultaneously to intensify their apology. Here's an example of the use of multiple strategies.

(2)对不起 ! ......我会承担相应的责任并接受处罚......我 今后一定会更加注重自身的言行......

I'm sorry! ... I will take responsibility and accept the punishment... I will pay more attention to my words and behavior in the future.

\subsubsection{Extensification}

Extensification refers to the action of making something more extensive or more general. Chinese celebrities tend to point out the victims in the apology, such as program groups, scholars, songwriters, women, but they also apologize to family members, friends, and fans, which seem to be irrelevant to the crisis. If there are no specific victims, they prefer to apologize to everyone (“大家”, “所有人”). It is because they care about their images and rapport with others, and they admit that their mistakes have caused troubles to innocent people. Here are some examples.

(3)在此我郑重地向平台的用户、节目组及支持我的粉丝 道兼。

I hereby solemnly apologize to the users of the platform, the program team and my fans.

(4)再次向所有人诚恳致兼。对不起。

I sincerely apologize to you all again. I'm sorry.

\subsubsection{Morals and Ethics}

In Chinese society, it is expected that a public figure can be seen as a role model, motivating others, especially youngsters to live meaningful lives. Many Chinese celebrities mentioned their influence, emphasizing that they should have set good examples for others, as in the following examples.

(5)每一位明星艺人所拥有的一切, 都是社会公众所赐予 的, 因此更应当做好表率, 对自己的作品负责, 对所有合 作伙伴负责。

Everything that an entertainer has possessed is given by the public. Therefore, s/he should set a good example and be responsible for the work and all the partners.

(6)作为一个公众人物, 应该遵纪守法, 起到社会和行业 的模范带头作用。

As a public figure, I should abide by the law and set a good example for the society and the profession.

Specifically, many celebrities emphasize that they are public figures, and their occupation demands ethics and morals. It is possible that their inappropriate remarks and illegal or immoral behavior bring about bad influence on society. Compared with foreign public figures, Chinese counterparts seem to pay more attention to “艺德” (morals for entertainers), which stems from Chinese conventions and “core socialist values". For example,

(7)今后我一定努力加强自身“艺德”建设, 提高自律意识。

In the future, I will work hard to have better morals and improve my self-discipline awareness.

(8)牢记“从艺路上德为先”, 努力成为德才兼备的好演员。

(I will) keep in mind "morals come first for entertainers", and strive to become a good actor with both integrity and professional competence.

From the data analysis, apology strategies have no significant differences in semantic structure between Chinese and other languages from the CCSARP project. In other words, in Chinese as well as in other languages, IFID and Taking on Responsibility are the most frequently employed strategies [11], followed by making explanations or accounts and offer repair for the damages caused, and finally comes the promises 
that the offense will never happen again.

\subsection{Image Repair Strategies}

After analyzing the apology formulas employed by Chinese celebrities, how they restore their images will be discussed. The data is analyzed according to Benoit's image repair scheme and Table 3 reveals the result. Then, we will analyze these strategies in detail with some cases elicited from the data.

Table 3. Frequency and percentage of the five image repair strategies

\begin{tabular}{lll}
\hline Type & Number & Percentage (\%) \\
\hline Denial & 4 & 7.69 \\
Evade Responsibility & 9 & 17.31 \\
Reduce Offensiveness & 16 & 30.77 \\
Corrective Action & 11 & 21.15 \\
Mortification & 12 & 23.8 \\
Total & 52 & 100 \\
\hline
\end{tabular}

As illustrated in Table 3, Reduce Offensiveness is the most common strategy, with more than $30 \%$ of celebrities employing it to reduce negative feelings and repair the image. Mortification is the second frequent strategy, and nearly one-fourth of Chinese celebrities admit committing the offensive action without any excuses and to ask for forgiveness via apology. Denial is the least frequent strategy, probably because the crisis they are facing displays sufficient evidence and they cannot or don't want to lie.

\subsubsection{Denial}

It is generally acknowledged that the strategy of Denial contains two sub-categorizations, Simple Denial and Shift Blame. Please look at the following examples.

i. Simple Denial

Simple Denial can take three forms, namely, deny committing the offense, deny the offense occurred, and deny the offense caused any harm [14].

(9)今天, 在我全力配合的彻底调查之后, $X$ 市 $Y$ 县检 察官办公室宣布将不会对我提起任何指控, 这个结果 证明了自始至终我都没有触犯任何法律。

Today, after a thorough investigation in which I fully cooperated, the Y County Prosecutor's Office in X announced that it would not bring any charges against me. This result proves that I have not violated any law from beginning to end.

Liu, a married Chinese tech entrepreneur, was arrested on suspicion of criminal sexual conduct and sparked heated online discussion. Later, the officials announced that "no charges will be filed against Liu for an alleged sexual assault" for the lack of evidence. Liu, therefore, posted a letter on Weibo, claiming he is innocent. His words "I have not violated any law" is a denial of the accusation against him, which can be categorized as "deny the offense occurred". The selection of words in this letter is quite careful, with "I have not violated any law" (because of inadequate evidence) instead of "I have nothing to do with the victim's allegation."

(10)我完全没有任何利益, 也没有参与内容, 更不知情 况, 没有经手任何课程, 卖课指的是中间有获得利益, 我完全没有...
... I have no profit at all, I'm not involved in selling the lesson, and I didn't know the situation. Selling lessons means that I got profits in the process, and I didn't...

$\mathrm{Yi}$, an actress, promoted a spiritual course of a so-called Indian religious master on Weibo. Netizens and authorities soon found that it's a "religious cult", and they suspected that Yi sold the course to earn a commission. After a heated discussion, she deleted the promotion and sent another post to deny the charges that she is involved in this course and got money from selling it. She used several "not" to deny every possible accusation to save her image, which can be categorized as "deny committing the offense."

ii. Shift Blame

Shift Blame, another form of Denial, occurs when the offender argues that others should be blamed, and s/he has no idea how the crisis happened. It's a way to get rid of the crisis and save reputation.

(11)关于版权方面的全部事宜在整个巡演开始前, 我 公司就已经全权交由巡演主办方去处理,而这些也都 是白纸黑字写在与主办方的合同里, 作为主办方必要 工作的部分去执行。

Before the concert tour, our company had delivered all copyright-related matters to the tour organizers, which was written in the contract as a necessary part of their work.

A musician claimed on Weibo that his song was performed by a singer Mao in a concert tour without buying copyright. A few days later, Mao posted an apology to explain that the copyright matters were handled by tour organizers, and he thought that the copyright had been settled and he didn't know he committed copyright infringement. Therefore, Mao successfully shifts the blame to the organizer who's in charge of the copyright matters according to the contract and saves his reputation.

\subsubsection{Evade Responsibility}

Evade Responsibility can assume four forms, Provocation, Defeasibility, Accident and Good Intentions. The latter three forms can be found in the following examples.

i. Defeasibility

Defeasibility means that the accused claims that $\mathrm{s} /$ he lack the information or ability to stop the offensive act, which can help the accused get rid of the responsibility.

(12)在此合作前, 并未获知该品牌于十多年前曾经发生 过辱华事件。

Before the cooperation, we didn't know that the brand insulted China more than a decade ago.

Martial arts actor Zhen recently had a runway show for a German brand, but Chinese netizens found that this brand has "humiliated" China years ago with insulting remarks on its products. The studio of Zhen apologized on Weibo soon and explained that they didn't know the brand's offense against China in the past. The ignorance of the insults separates them from the offensive action.

ii. Accident

The accused can argue that the offensive act does not occur purposely but accidentally. Since accidents happen randomly, it is hard to avoid them. For example, 
(13)由于 2019 年之前我没有签署任何公司团队, 所有事 宜均由我自己及身边朋友打理, 在打包上传平台时出现 工作疏漏, 导致如今的情况发生, 在此向大家正式道兼!

Since I didn't sign any company before 2019, all the matters were handled by friends and myself, and there was a job omission when uploading the packaged songs to music platforms, resulting in the current situation. I apologize to everyone.

Hua is a young singer who writes a lot of songs. After netizens found that one of Hua's songs was the same as a Russian folk song, they criticized her for plagiarism and infringement. Then Hua apologized and claimed that the song was a cover version of the Russian song and it was not intended to be released. She explained that she was an independent musician, dealing with all the stuff with her friends, and the infringement turned out to be an accident.

iii. Good Intentions

The accused can also claim that the offensive behavior was initially done with good intentions. Due to different reasons, the consequence deviates from the real intention.

(14)我全文没有倡导性开放……而举例是提醒大家 尊重对方, 不要以爱的名义骗炮。

My whole speech doesn't advocate sex openness... My example is to remind everyone to respect your mate and do not cheat in the name of love.

After Liu's scandal in case (1), Li, another influential entrepreneur, supported Liu on Weibo and justified cheating on a spouse by saying "pure sex without being in an extramarital affair does little harm to his wife". Being criticized by netizens for his inappropriate remarks, $\mathrm{Li}$ apologized and explained that his speech was to remind people of frauds in the name of love and respect each other, rather than support cheating. His explanation seems to impose good intentions on his controversial remarks.

\subsubsection{Reduce Offensiveness}

There are six different forms of Reduce Offensiveness, and five of them are identified in the cases we collected.

\section{i. Bolstering}

The offender can bolster his or her image to strengthen positive feelings and offset negative feelings. For example,

(15)我从小喜欢艺术, 又赶上了影视业蓬勃发展的 好时机，在诸多前辈的提携和观众朋友的爱护下， 加之自己的不断努力, 这才在演艺方面取得了一点 成绩。作为一个演员, 我常为自己能在世界舞台上 展示我国文化而自豪，并不遗余力为此冲锋。

I have been an art lover since I was a child, and I have caught up with the good opportunity of the booming of the film and television industries. With the guidance of many veterans and the love of the audience, together with my hard work, I have made a little achievement in my career. As an actress, I take pride in showcasing Chinese culture on the world stage, and I spare no effort to do it.

Fan, a well- known Chinese actress, was reported as being fined for tax evasion in 2018. In her apology, she tried to describe her positive characteristics and her efforts in the past to offset negative impressions. She emphasized her modesty and diligence, trying to evoke people's sympathies and repair her image.

(16)正是出于对学习的重视, 我决定攻读研究生。 研究生就读期间, 我参加了一系列影视作品的拍摄, 并有幸取得了一点成绩。

I gave particular importance to learning; therefore, I decided to pursue a master's degree. During my postgraduate studies, I starred in some films and TV series, and fortunately, I made some achievements.

In 2019, Zhai, a Chinese film star, shared the news that he was accepted as a post-doctoral student on Weibo. However, netizens found that Zhai was far from being qualified to get the doctorate and accused him of academic plagiarism. Later, Zhai posted an apology letter on Weibo, accepting responsibility for his academic misconduct. Expressions of his pursuit of higher education, together with his self-blame for vanity shape an image of an aspirant and hard-working actor but his eagerness for quick success and instant benefit ruined his integrity. This strategy will alleviate the bad influence of the scandal if it works.

ii. Minimization

The accused can claim that the act is less offensive than it seems to downplay the extent of offense. For example,

(17)我承认自己前两天言行失当, 难以相信自己当 时竟是如此情绪化。

I admit that my words and behavior were inappropriate the other day. I can't believe I was so emotional.

Zeng, a singer, claimed one day that the border police treated her unfairly, and then she posted the inspector's name and badge number. But after investigation, things turned out to be the opposite: Zeng was uncooperative and swore at officers Later, she deleted the previous posts and apologized. Her behavior has violated related rules and received heavy criticism, but in her apology, she attempted to downplay the extent of the damage, referring to it as "inappropriate words and behavior" to minimize the severity and negative feelings of her offense as much as possible.

iii. Differentiation

The accused can also compare the behavior to similar but less offensive acts or put it in a favorable context.

(18)今天我某个论坛上阐释“衡量评价的方向决定 了教育的方向”这一论点时，用了女人找男人的标 准做例子, 由于没有表达好, 引起了广大网友的误 解, 在此深表兼意。

Today, when I explained the argument that "the direction of evaluation determines the direction of education" in a forum, I used the criterion Chinese women use to choose men as an example. Since I did not express it well, it caused misunderstandings. I apologize for this.

At a business forum, Yu, one of China's best-known entrepreneurs, claimed that "degeneration of Chinese women has led to degeneration of the nation," later, he reiterated his point that "women have destroyed China." Yu's remarks irritated all the Chinese women, especially in the context of feminism. In his apology, he tried to explain that he intended to emphasize that the values of women represent the values of the country. If women are money-oriented, men will pursue 
money and neglect spiritual cultivation; therefore, the values of women are crucial to the success of the country. Clearly, Yu tried to distinguish the "misunderstanding" of his remarks from underestimating women, which is more offensive.

iv. Attacking Accuser

The offender can attack the accusers, reducing the credibility of the source of allegations. For example,

(19)我在发现情况后, 已经尽快删除, 明知内容有 争议, 娱乐大号卻拉上我家人, 只想增加八卦谈 资.......

After I am aware of the situation, I delete it as soon as possible. Knowing the content is controversial, entertainment accounts try to pull on my family and create gossips and rumors...

Yi, the same actress as in case (2), also attacked the accusers. Being criticized by netizens for selling lessons illegally, Yi blame the misleading of entertainment accounts who intentionally exaggerates her mistake and damages her reputation, even her family's. Her utterances attack the accusers, lower their credibility, and repair her image.

v. Compensation

The offender can make compensation to the victim to offset the negative impression and repair the image.

(20)我已经第一时间向她坦承了事实, 希望她可以

接受我最诚恳的道兼, 我一定将竭尽全力去弥补此 事对家庭的创伤，重新担当起丈夫的责任。

I have admitted the truth to her immediately and hope that she can accept my sincere apology. I will do my best to make up for the trauma of this incident to the family and take on my responsibilities as a husband again.

In case (1), Liu denied the accusation, but the scandal damaged his image and hurt his wife. In order to repair his image and offset negative impressions, he promised to compensate his wife, one of the victims of this scandal, and make up for the damage to the family.

\subsubsection{Corrective Action}

Corrective Action can take two forms, correct the current problem or prevent future recurrence of the offense. The willingness to correct or prevent mistakes can restore the image of the accused.

(21)对税务机关调查后，依法作出的一系列处罚决 定, 我完全接受, 我将按照税务部门的最终处罚决 定, 尽全力克服一切困难, 筹措资金、补缴税款、 缴纳罚款。

After an investigation of the tax authorities, I completely accept the punishment according to law. I will try my best to overcome all difficulties, raise funds, pay taxes, and pay fines according to the final punishment decision of the tax authorities.

Fan in case (2) accepted the punishment and showed her willingness to correct the problem as soon as possible. Corrective action can not only control the expansion of scandal but also alleviate negative influence and repair the image.

\subsubsection{Mortification}

Mortification is to admit the guilt and beg forgiveness. If audiences or victims believe the apology is sincere, the offender's image can be restored.

(22)对不起 XX, 我冲动的行为伤害了你和你的家 人, 不论什么原因, 我都不应该动手, 我为自己的 行为感到差愧。不做任何辩解, 我会为自己的行为 负起责任，接受惩罚。

I'm sorry, XX. My impulsive behavior hurts you and your family. No matter what the reason is, I should not have hurt you. I am ashamed of my actions and won't make excuses in any way. I will bear the consequences of my behavior and accept the punishment.

The apologizer Jiang is a Chinese movie and TV star. In 2018, his Japanese girlfriend posted photos of her bruised face and body on social media and charged Jiang with abusing her. Soon after, Jiang was accused of domestic violence. Later, he posted an apology on Weibo and confessed to abusing his girlfriend. Jiang did not minimize the offensiveness or make any excuses for his behavior, and this is a typical example of Mortification.

\subsection{Mitigation Strategies}

This study also discovers some mitigating strategies that help restore the image, including reposting with an apology, releasing a video, apologizing personally, and writing a letter in one's own handwriting.

\subsubsection{Repost with Apologies}

Some of the apologies are posted by the celebrity's studio or company. Then the celebrity reposts the apology with several sentences to express sorry. An apology posted by a studio or company can be seen that all staff should shoulder the responsibility and they attach great importance to the crisis.

\subsubsection{Release a Video}

A singer who violates the contract against a program released a video as well as the full text of apology on Weibo. In the video, he explained the crisis and apologized many times to set a positive image and restore rapport with the offended. It takes courage to release videos to apologize, and this behavior shows his honesty and frankness.

\subsubsection{Apologize in Person}

Being accused of underestimating women, $\mathrm{Yu}$ explained and apologized on Weibo, and then he went to All-China Women's Federation, a women's rights organization, to apologize in person. He expressed his anxiety and self-blame and promised to publicize equality between men and women in the future. Soon reports on Yu's apology are posted on Weibo and criticism decreases.

\subsubsection{Write a Letter}

To write a letter in one's handwriting is another strategy of mitigation. Because we are getting used to ubiquitous electronic devices, hand-written letters have become more precious and sincere than ever. $\mathrm{Xu}$, an actress, posted a photo of her hand-written letter on Weibo, apologizing for the mistake of accidentally click on the like button for other's inappropriate posts. Together with the hand-written letter, her 
apology and corrective action seem to be sincerer than others, and her image can be repaired.

\section{Conclusion}

This article has investigated apology strategies and image repair strategies employed by Chinese celebrities on Weibo. It is found that IFID, the direct realization of an apology is the most frequent strategy, followed by Taking on Responsibility and Explanation or Account, and celebrities prefer to combine three or four strategies together in an apology. Specifically, two IFID types in Chinese, namely “差愧”(be shamed, be embarrassed) and “反省”(self-examination) are different from western languages in previous studies. Moreover, Chinese public figures pay more attention to morals and their influence, and they are willing to set good examples for others. In accordance with image repair theory, Evade Offensiveness and Mortification are preferred in their apologies to offset negative influence and restore the image. In addition, some mitigation strategies for boosting the image can be seen, like releasing a video or uploading a hand-written letter. Although the Chinese people attach great importance to "face," direct ways like IFID and Mortification are employed frequently in the apology. As public figures, celebrities tend to admit committing mistakes and use other strategies to show that they are sincere and truly sorry for what they have done.

However, this paper has some limitations. First, in analyzing apology strategies, we failed to adequately consider other factors like gender, social distance, types of crises, which are influential and can explain more facts. Second, the data is insufficient, which may result in differences between our findings and the reality. Third, the perception of the audience is not calculated to evaluate the effectiveness of the apology. Considering these defects, we strongly suggest that more factors be involved in analyzing apology strategies, more data be collected to ensure representativeness and the effectiveness of the apology be evaluated by conducting questionnaires or interviews in future research.

\section{Acknowledgments}

The authors gratefully acknowledge the research grant (17SS03) delivered by Guandong University of Foreign Studies, and the support provided by the Research Centre for Business Culture and Philosophy of Culture, Guangdong University of Foreign Studies.

\section{References}

[1] Brooks, R. L. (1999). When sorry isn't enough: The controversy over apologies and reparations for human injustice. New York: New York University Press.

[2] Chen, J. (2015). A pragmatic study of Chinese corporate apologies posted on Weibo. Guangdong University of Foreign Studies, China.

[3] Yang, W. X. (2017). A Study of the Image Restoration
Discourse on Micro-blog Apologies Posted by Entertainment Celebrities. Fujian Normal University, China.

[4] Cui, P. K (2014). Study in Government Weibo Utterances from the Speech Act Theoretic Perspective. East China Normal University, China.

[5] Hu, L. B. C. (2015). Study of governmental "Micro-apology" in crisis communication strategy. Journal of the Party School of Guizhou Provincial Committee of the C. P. C, 4, 101-104.

[6] Olshtain, E. and Cohen, A. (1983). Apology: a speech act set. Sociolinguistics and Language Acquisition. Rowley: Newbury House.

[7] Holmes, J. (1990). Apologies in New Zealand English. Language in Society, 19 (2), 155-199.

[8] Trosborg, A. (1995). Interlanguage Pragmatics: Requests, Complaints and Apologies. Berlin/New York: Mouton de Gruyter.

[9] Blum-Kulka, S., and Olshtain, E., (1984). Requests and apologies: a cross-cultural study of speech act realization patterns (CCSARP). Applied Linguistics, 5, 196-213.

[10] Shahrokhi, M., and Jan, J. M. (2012). The Realization of Apology Strategies Among Persian Males. Procedia - Social and Behavioral Sciences, 46, 692-700.

[11] Afghari, A. (2007). A sociopragmatic study of apology speech act realization patterns in Persian. Speech Communication, 49 (3), 177-185.

[12] Kadar, D. Z., Ning, P. Y. and Ran, Y. P. (2018) Public ritual apology - A case study of Chinese. Discourse, Context \& Media, 26, 21-31.

[13] Kampf, Z. (2009). Public (non-) apologies: The discourse of minimizing responsibility. Journal of Pragmatics, 41 (11), 2257-2270.

[14] Benoit, W. L. (1997). Image Repair Discourse and Crisis Communication. Public Relations Review, 23 (2), 177-186.

[15] Page, R. (2014). Saying 'sorry': Corporate apologies posted on Twitter. Journal of Pragmatics, 62, 30-45.

[16] Sandlin, J. K., and Gracyalny, M. L. (2018). Seeking sincerity, finding forgiveness: YouTube apologies as image repair. Public Relations Review, 44, 393-406.

[17] Zhang, A. L. (2018). A Review on the Study of Apology Expressions at Home and Abroad. Overseas Chinese Education, $5,131-137$

[18] Austin, J. L. (1962). How to do things with words. London: Oxford University Press.

[19] Searle, J. R. (1979). Expression and Meaning: Studies in the Theory of Speech Acts. Cambridge: Cambridge University Press.

[20] Leech, G. N. (1983). Principles of Pragmatics. London: Longman.

[21] Goffman, E. (1959). The Presentation of the Self in Everyday Life. New York: Anchor Books.

[22] Brown, P., and Levinson, S. (1987). Politeness: Some Universals in Language Use. Cambridge: Cambridge University Press. 
[23] Wang, M. (2010). A Survey of Apology Studies Abroad. Journal of University of Science and Technology Beijing (Social Sciences Edition), 2, 107-112.

[24] Demeter, G. (2000). A Pragmatic Study of Apology Strategies in Romanian, North University of Baia Mare, Romania.

[25] Benoit, W. L. (1997). Hugh Grant's image restoration discourse An actor apologizes. Communication Quarterly, 45, 251-267.

[26] Benoit, W. L. (1999). Queen Elizabeth's Image Repair Discourse: Insensitive Royal or Compassionate Queen? Public Relations Review, 25 (2): 145-156.
[27] Benoit, W. L., and Henson, J. R. (2009). President Bush's image repair discourse on Hurricane Katrina. Public Relations Review 35 (2009) 40-46.

[28] Benoit, W. L. (2014). President Barack Obama's image repair on HealthCare. gov. Public Relations Review, 40 (5), 733-738.

[29] Blum-Kulka, S., House, J. and Kasper, G. (Eds.), (1989). Cross-Cultural Pragmatics: Requests and Apologies. Norwood, NJ: Ablex Publishing Corporation. 